\title{
DEFINING AND ASSESSING CONGESTION INSIDE METRO TRAINS AND AT STATION: CASE STUDY OF DELHI METRO, INDIA
}

\author{
Pradeep Kumar Sarkar ${ }^{1}$, Amit Kumar Jain ${ }^{2}$ \\ ${ }^{1}$ School of Planning and Architecture, Delhi, India \\ ${ }^{2}$ Indian Railways, Delhi, India
}

Received 3 February 2016; accepted 16 September 2016

\begin{abstract}
Congestion in metro trains and stations during peak hours is one of the major challenge being faced by the metro train operators. The metro trains and stations typically remain very crowded during the peak hours and relatively empty during the non peak hours. An optimum combination of demand and supply side measures may be effective to ease out peak hour congestion inside the metro trains. However, the first step is to assess the congestion in quantifiable terms so that the efficacy of demand and supply management measures may be assessed objectively. This paper discusses the concepts of congestion at walkway \& Platform of station and inside the trains. The concept of Level of Service (LOS) to define the congestion has been presented. The LOS for walkway and platform has been defined on the basis of Fruin's model. The present LOS in F Block of Rajiv Chowk Metro station of Delhi Metro in India at different point of time in a day has been observed on the basis of CCTV images. The present LOS at one of the busiest Platform of Rajiv Chowk metro station has also been assessed using the CCTV images. The criteria for LOS inside metro trains has been developed and the LOS inside the train has been assessed for a controlled number of users inside the trains. It has been observed that the congestion inside train is the most critical which requires to be addressed while adopting the demand and supply measure tools. The LOS at the busiest platform, Walkway and inside trains at Rajiv Chowk station of yellow line (Busiest line) of Delhi Metro in India are found to be C, D \& E respectively. Since LOS is the worst inside trains, any criteria to ease congestion during peak hour should be focused on improving LOS inside the trains. The metro train operators should aspire to achieve an LOS of D inside the trains.
\end{abstract}

Keywords: urban transportation, transport demand management, elasticity, differential pricing, congestion.

\section{Introduction}

A condition of more number of users than the desirable level, which causes inconvenience to the users, is termed as congestion. In simple words, congestion is a condition of overcrowding, the extent may differ. In context of urban rail transport system, the passengers may feel congestion at the station and inside the trains due to overcrowding. The congestion results into inconvenience to the passengers, slower speed of movement, poor ventilation conditions (in enclosed space like train). In urban rail transport systems, the

${ }^{2}$ Corresponding author: jainakirts@yahoo.co.in 
congestion needs to be monitored at following locations: a) inside trains; b) at station (in walkway or at platform).

Once level of congestion is known, the next step is to take suitable measures to ease the congestion. The measures like increasing train frequency, number of cars per train, speed of the trains etc are termed as supply side measures as capacity offered is being increased to address the congestion. The measures to control or level the demand like higher fares during peak hours, congestion pricing, staggered office timing etc are called demand side measures (Broaddus et al., 2009; Hale and Charles, 2009). An optimum combination of supply and demand side measures to ease congestion may be quite effective. To assess the efficacy of any measure(s), it is important to objectively assess the congestion. The Level of Service (LOS) concept is widely used to define congestion in transport sector.

\section{Level of Service (LOS)}

Traditionally, the use of level of service (LOS) has been one of the most popular measures of traffic congestion (Henn et al., 2010). The LOS concept as adopted in the 1985 Highway Capacity Manual represents (Aftabuzzaman, 2007), a range of operating conditions. Six LOS letters are defined by HCM, namely A, B, C, D, E, and F, where $A$ denote the best quality of service and $F$ denote the worst. Level of service (LOS) is a qualitative measure used to relate the quality of traffic service. LOS is used to analyze highways by categorizing traffic flow and assigning quality levels of traffic based on performance measure like speed, density, etc. The concept of LOS can also be used to define quality of service at critical locations of a transit system like walkway, concourse, platform and inside trains. The primary measure of effectiveness for defining pedestrian level of service is the average space available to each pedestrian. The level of service for a pedestrian waiting area is based not only on space but also the degree of mobility allowed. In dense standing crowds, there is little room to move, but limited circulation is possible as the average space per pedestrian increases.

Level-of-service descriptions for passenger waiting areas have been developed based on average pedestrian space, personal comfort, and degrees of internal mobility. The standards are presented in terms of average area per person and average interpersonal space (distance between people).

The level of service required for waiting within a facility is a function of the amount of time spent waiting and the number of people waiting. Typically, the longer the wait, the greater the space per person required. Also, the required space per person may vary over time. For example, those waiting in the beginning will want a certain amount of space initially, but will be willing to accept less space as additional people arrive later.

A person's acceptance of close interpersonal spacing will also depend on the characteristics of the population, the weather conditions, and the type of facility. For example, commuters may be willing to accept higher levels or longer periods of crowding than intercity and recreational travelers.

\section{About Delhi Metro Rail Corporation}

Delhi Metro Rail Corporation (DMRC) was incorporated in 1998 to construct, operate and maintain Metrorail services in Delhi, the capital city of India. Till date, DMRC has 212.5 
$\mathrm{km}$ network with 160 stations, commuting 2.7 million passengers a day, maximum being 3.0 million. In DMRC, the peak hour demand (mornings \& evenings) on weekdays is around $70 \%$ higher than the non peak hour demand. Like any other metro systems of major cities of the world, DMRC is grappling with the problem of extreme congestion especially in peak hours. The present network of DMRC is shown in Exhibit 1.

\section{Level of Service in Walkway at Station}

The LOS at walkway at station has been defined in Chapter 3 of Transit Service and Quality of Service Manual- 2nd Edition, TRB (Roess et al., 1985a) on "Passenger Circulation and Level of service' defines the LOS for walkways, circulating areas and waiting areas using Fruin Principle ${ }^{7}$ of Level of service.

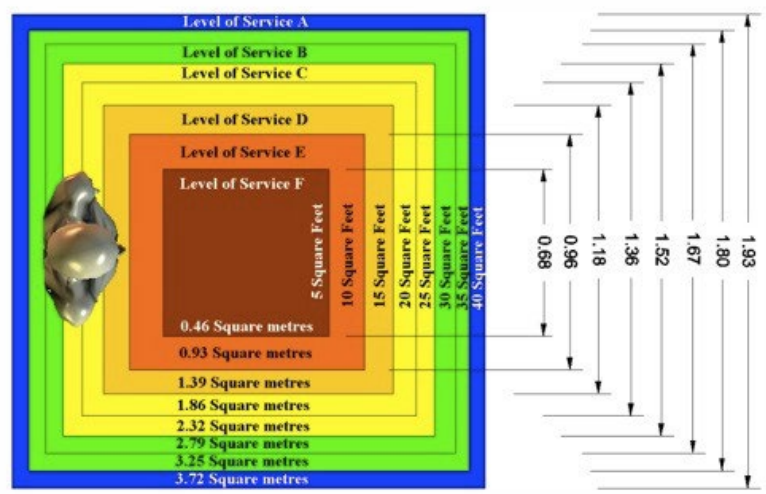

Fig. 1.

Fruin's Level of Service

Table 1

Level of Services as per Fruin's Model for Walkway

\begin{tabular}{|c|c|c|c|c|}
\hline Level & Description & Pedestrian /sqm & $\begin{array}{c}\text { Avg speed } \\
(\mathrm{m} / \mathrm{min})\end{array}$ & $\begin{array}{c}\text { Flow per unit width } \\
(\mathrm{p} / \mathrm{m} / \mathrm{min})\end{array}$ \\
\hline $\mathbf{A}$ & $\begin{array}{l}\text { Walking speeds freely selected, conflicts with } \\
\text { other pedestrians unlikely }\end{array}$ & $\leq 0.3$ & 79 & $0-23$ \\
\hline B & $\begin{array}{l}\text { Walking speeds freely selected, passengers } \\
\text { respond to presence of others }\end{array}$ & $0.3-0.42$ & 76 & $23-33$ \\
\hline $\mathbf{C}$ & $\begin{array}{l}\text { Walking speeds freely selected; passing is } \\
\text { possible in unidirectional streams; minor } \\
\text { conflicts for reverse or cross movement }\end{array}$ & $0.42-0.71$ & 73 & $33-49$ \\
\hline D & $\begin{array}{l}\text { Freedom to select walking speed and pass } \\
\text { others is restricted; high probability of conflicts } \\
\text { for reverse or cross movements }\end{array}$ & $0.71-1.11$ & 69 & $49-66$ \\
\hline $\mathbf{E}$ & $\begin{array}{l}\text { Walking speeds and passing ability are } \\
\text { restricted for all pedestrians; forward } \\
\text { movement is possible only by stuffing; reverse } \\
\text { or cross movements are possible only with } \\
\text { extreme difficulty; volumes approach limit of } \\
\text { walking speed }\end{array}$ & $1.11-2$ & 46 & $66-82$ \\
\hline $\mathbf{F}$ & $\begin{array}{l}\text { Walking speeds are severely restricted; frequent } \\
\text { unavoidable contract with others; reverse or } \\
\text { cross movements are virtually impossible; flow } \\
\text { is sporadic and unstable }\end{array}$ & $\geq 2$ & $<46$ & Variable \\
\hline
\end{tabular}




\subsection{Observations of LOS in F Block of Rajiv Chowk Metro station of Delhi Metro, India}

The LOS at different times of the day has been observed in F Block of Rajiv Chowk metro station as F block is one of the most crowded walkway of Delhi Metro system in India. The CCTV footages of a day (Feb
24, 2014) for F Block as shown in Fig. 2 have been used to assess the number of passengers per sqm and the walking speed of the passengers in the predefined area. The observed LOS at different point of time in morning hours are presented in Table 2. The detailed calculation of LOS in F Block of Rajiv Chowk Metro station is presented at Annex A.

\section{Table 2}

LOS Observation at Rajiv Chowk Metro Station, Delhi Metro, India (Feb 24, 2014)

\begin{tabular}{|c|c|c|c|c|}
\hline \multirow{2}{*}{ Location } & Time & Pax/sqm & $\begin{array}{c}\text { Average Speed } \\
(\mathbf{m} / \mathbf{m i n})\end{array}$ & LOS \\
\hline \multirow{3}{*}{$\begin{array}{c}\text { F Block of } \\
\text { Rajiv Chowk }\end{array}$} & $8: 00$ & 0.14 & 90.43 & $\mathrm{~A}$ \\
\cline { 2 - 5 } & $9: 00$ & 0.19 & 84.4 & $\mathrm{~A}$ \\
\cline { 2 - 5 } & $9: 50$ & 0.35 & 76.2 & $\mathrm{~B}$ \\
\hline
\end{tabular}

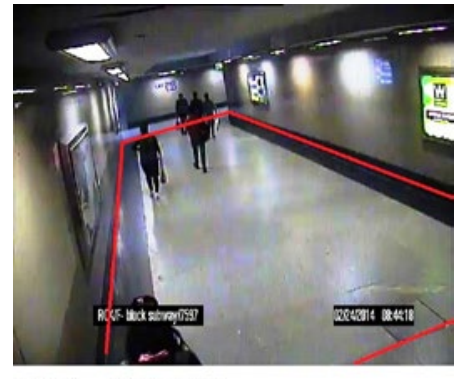

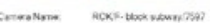

Observed area ( $L 21.6 m \times W 4.2 \mathrm{~m}$ ) Actual width $=4.8 \mathrm{~m}$, Side margins $=0.3 \mathrm{~m}$, Effective width $=4.2 \mathrm{~m}$

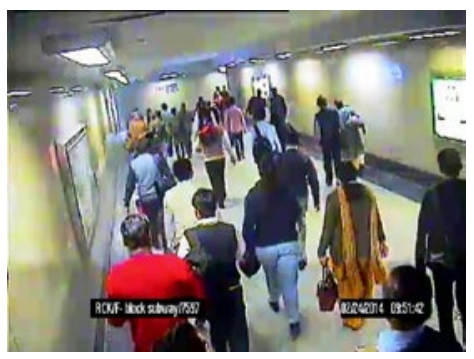

$\operatorname{LOS} B$

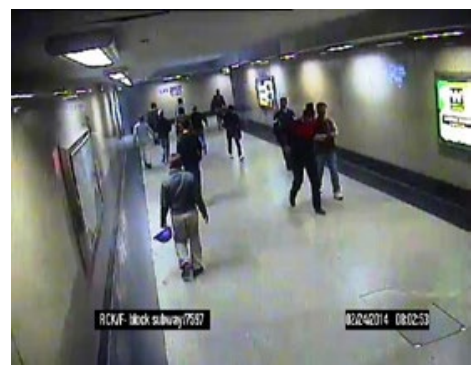

$\operatorname{LOS} A$

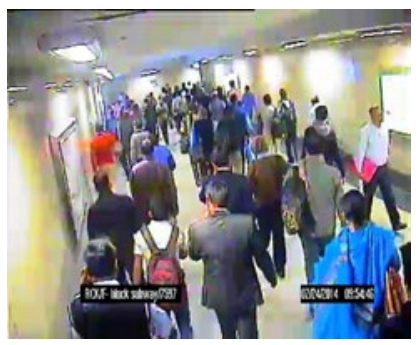

LOS C

Fig. 2.

LOS Observation at Rajiv Chowk Metro Station 
Evidently, the LOS is gradually reducing from $\mathrm{A}$ to $\mathrm{C}$ from $8 \mathrm{AM}$ to $10 \mathrm{AM}$ as rush is building up in the morning peak hours. The lowest LOS C has been observed at around 9:55 AM which is the morning peak hour.

\section{LOS at Platform Level}

The waiting time at platform level is usually low as trains are available at a close headway (an average headway of 3 mins in Delhi Metro). The passengers are willing to accept more congestion while waiting for the train. The LOS at platform of a station has been defined in Chapter 4 of Transit Service and Quality of Service Manual- 2nd Edition on "Station elements and their capacities' (Roess et al., 1985b). It defines the LOS for waiting areas using Fruin Principle (Fruin, 1987) of Level of service as presented in Table 3.

Table 3

LOS at Platform Level (Fruin, 1987)

\begin{tabular}{|c|c|c|}
\hline Level & Description & Pax /sqm \\
\hline A & Standing \& Free circulation through queuing area possible without disturbing others \\
within the queue & possible & 0.83 \\
\hline B & $\begin{array}{c}\text { Standing \& partially restricted circulation to avoid disturbing others within the queue is } \\
\text { possible; this density is within the range of personal comfort }\end{array}$ & $0.83-1.11$ \\
\hline C & $\begin{array}{c}\text { Stranding and restricted circulation through the queuing area by disturbing others is } \\
\text { is discomforting. }\end{array}$ & $1.11-1.43$ \\
\hline D & $\begin{array}{c}\text { Standing without touching is impossible; circulation is severely restricted within the } \\
\text { queue and forward movement is only possible as a group; long-term waiting at this density }\end{array}$ & 3.33 \\
\hline E & $\begin{array}{c}\text { Standing in physical contact with others is unavoidable; circulation within the queue is } \\
\text { not possible; queuing at this density can only be sustained for a short period without } \\
\text { serious discomfort. }\end{array}$ & $3.33-5$ \\
\hline F & $\begin{array}{c}\text { Virtually all persons within the queue are standing in direct physical contact with others; } \\
\text { this density is extremely discomforting; no movement is possible within the queue; the } \\
\text { potential for pushing and panic exists. }\end{array}$ & $\geq 5$ \\
\hline
\end{tabular}

\subsection{Observation of Level of Service at Platform}

The level of service at a platform of Rajiv Chowk Metro station, Delhi Metro, India has been observed for evening peak hours for three conditions; just before arrival of the train, at the time of arrival of train, just after dispatch of train for a particular day (April $21,2014)$ using CCTV footage as shown in Fig. 3. The detailed assessment of LOS is presented at Annex B. 


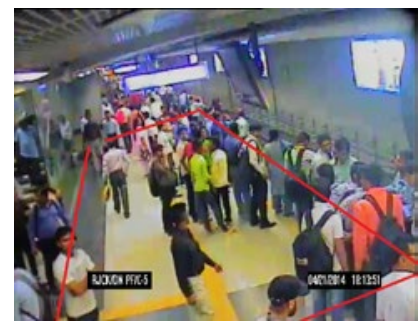

Observed Area

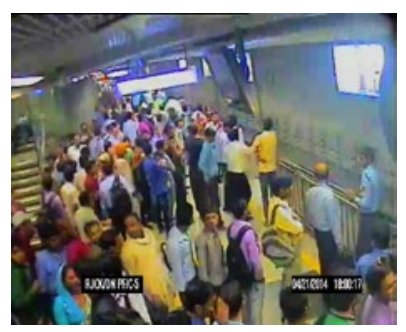

LOS C (Before arrival of train)

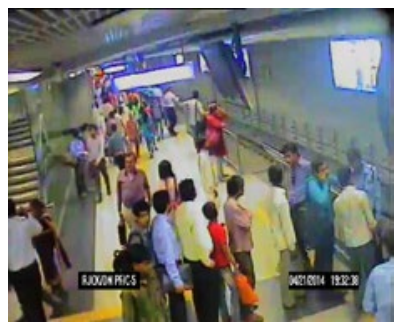

LOS A after departure of train

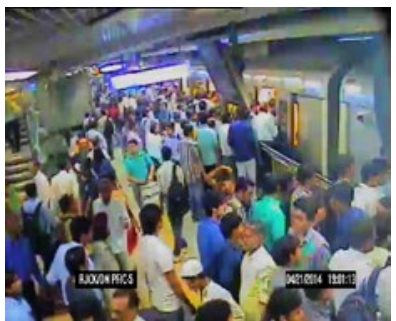

LOS D (with train at PF)

Fig. 3.

Observation of LOS at Rajiv Chowk Platform

Evidently, the LOS is minimum (D) when train is at platform and boarding \& alighting passengers jostle for space at platform.

\section{Level of Service Inside the Trains}

In general, the congestion inside the trains is defined on the basis of passengers per sqm. The higher the number of passengers per sqm, the higher the level of congestion inside the trains.

The congestion in some of the metro system is defined in Table 4 as under:

\section{Table 4}

Criteria of Congestion Across Some of the Metro Systems in the World

\begin{tabular}{|c|c|l|}
\hline SN & Metro System & \multicolumn{1}{c|}{$\begin{array}{c}\text { Criteria of congestion } \\
\text { (Source: official websites of concerned metro system) }\end{array}$} \\
\hline $\mathbf{1}$ & Tokyo, Japan & $\begin{array}{l}\text { Capacity- standing } 3.7 \mathrm{p} / \mathrm{m}^{2} \\
150 \% \text { congestion }- \text { standing space } 6.5 \mathrm{ps} / \mathrm{m}^{2} \\
180 \% \text { congestion }- \text { standing space } 8.3 \mathrm{ps} / \mathrm{m}^{2} \\
200 \% \text { congestion }- \text { standing space } 9.4 \mathrm{ps} / \mathrm{m}^{2}\end{array}$ \\
\hline $\mathbf{2}$ & Beijing, China & $\begin{array}{l}\text { Capacity - standing } 6 \mathrm{ps} / \mathrm{m}^{2} \\
\text { Congested - standing } 9 \mathrm{ps} / \mathrm{m}^{2}\end{array}$ \\
\hline $\mathbf{3}$ & London UG, UK & $\begin{array}{l}\text { Capacity - Standing } 6 \mathrm{ps} / \mathrm{m}^{2} \\
\text { Congested }>\text { Standing } 6 \mathrm{ps} / \mathrm{m}^{2}\end{array}$ \\
\hline $\mathbf{4}$ & Paris (RATP), France & $\begin{array}{l}\text { Capacity - Standing } 4 \mathrm{ps} / \mathrm{m}^{2} \\
\text { Congested }>\text { Standing } 4 \mathrm{ps} / \mathrm{m}^{2}\end{array}$ \\
\hline $\mathbf{5}$ & Hong kong (MTR) & $\begin{array}{l}\text { Capacity - Standing } 6 \mathrm{ps} / \mathrm{m}^{2} \\
\text { Congested }>\text { Standing } 6 \mathrm{ps} / \mathrm{m}^{2}\end{array}$ \\
\hline $\mathbf{6}$ & Moscow, Russia & $\begin{array}{l}\text { Capacity - Standing } 4.5 \mathrm{ps} / \mathrm{m}^{2} \\
\text { Congested }>\text { Standing } 4.5 \mathrm{ps} / \mathrm{m}^{2}\end{array}$ \\
\hline $\mathbf{7}$ & Delhi Metro, India & $\begin{array}{l}\text { Operational Capacity }=\mathrm{standing} \mathrm{space} 6 \mathrm{ps} / \mathrm{m}^{2} \\
\text { Design Capacity }=\mathrm{standing} \mathrm{space} 8 \mathrm{ps} / \mathrm{m}^{2} \\
\text { Congestion }=\text { Actual passengers }>6 \mathrm{ps} / \mathrm{m}^{2}\end{array}$ \\
\hline
\end{tabular}




\subsection{Level of Service Inside Metro Trains}

In this study, an attempt has been made to define the congestion inside trains on the basis of level of service. The passengers are willing to accept a higher level of crowding inside the enclosed space. However, the acceptability of level of congestion also depends upon the travelling time. The passengers would not like to travel in congested train for longer distances/time. However, the commuters, who travel to their work place for a short period of time (say $<60 \mathrm{~min}$ ) may be willing to travel in comparatively congested trains also. On the basis of perceived willingness to travel, the proposed criteria of LOS for inside the trains has been presented in Table 5:

Table 5

Proposed Criteria - Level of Service Inside Metro Trains

\begin{tabular}{|c|c|c|c|c|}
\hline Level & Description & Passenger /sqm & $\begin{array}{c}\text { Capacity } \\
\text { utilization }\end{array}$ & $\begin{array}{l}\text { M car } \\
\text { capacity }\end{array}$ \\
\hline $\mathbf{A}$ & All passengers are sitting & No standing & & 45 \\
\hline B & $\begin{array}{l}\text { Passengers are comfortable, sitting on seat or holding } \\
\text { on to a strap or a pole near door and can stretch their } \\
\text { arms completely without touching anybody else }\end{array}$ & $<2$ & & 117 \\
\hline $\mathbf{C}$ & $\begin{array}{l}\text { Passengers are comfortable, sitting on seat or holding } \\
\text { on to a strap or a pole near door and can slightly } \\
\text { stretch their arms touching others }\end{array}$ & $2-4$ & $60 \%$ & 190 \\
\hline D & $\begin{array}{l}\text { Some passengers have to stand shoulder to shoulder } \\
\text { with others can move around with slight difficulty }\end{array}$ & $4-6 \mathrm{p} / \mathrm{sqm}$ & $100 \%$ & 261 \\
\hline $\mathbf{E}$ & $\begin{array}{l}\text { Many passengers are in physical contact with each } \\
\text { other but can't move around without pushing }\end{array}$ & $6-8 \mathrm{p} / \mathrm{qm}$ & $150 \%$ & 330 \\
\hline $\mathbf{F}$ & $\begin{array}{l}\text { Packed tight, no movement possible unless passengers } \\
\text { exit from the train doors at a station }\end{array}$ & $>8 \mathrm{p} / \mathrm{sqm}$ & $>150 \%$ & $>330$ \\
\hline
\end{tabular}

\subsection{Observation of LOS Inside the Trains}

The Level of service inside the train has been observed for a controlled number of users inside the trains. The following methodology has been used to measure level of service inside a metro train:

- The experiment was conducted in a train depot, where trains are parked for maintenance, on January 2, 2014.

- Total 300 users (trainee of Delhi Metro Training Institute) have been used in this experiment.

- The CCTV footage inside the trains has been used to observe congestion for different level of service (A to $\mathrm{E}$ ).

- First only users equal to the sitting capacity of a car of the train (45 in number) are entered in the car and Level of Service has been observed as shown in the Fig. 5.

- The number of users inside the car of the train are progressively increased to achieve 2, 3, 4, 5, 6 passengers /sqm as shown in Table C2 in Annex C.

- The LOS inside metro trains is assessed on the basis of proposed criteria in Table 3.

- The photographs for each LOS (except LOS F) have been taken from CCTV images and presented in Fig. 5.

- The congestion for LOS F couldn't be observed as total number of users were less than 330 .

The CCTV snap shots for different level of services inside the train are shown in Fig. 5. 


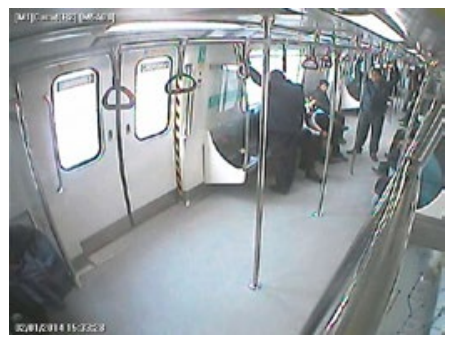

$\operatorname{LOS} A$

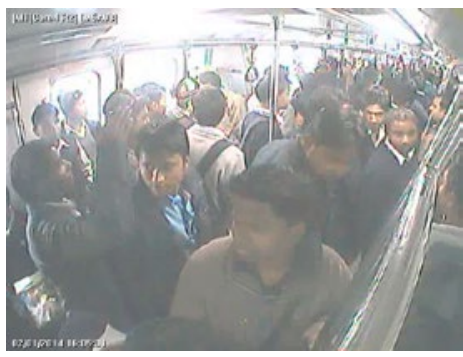

LOS C

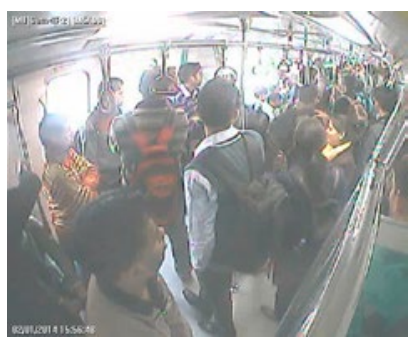

$\operatorname{LOS} B$

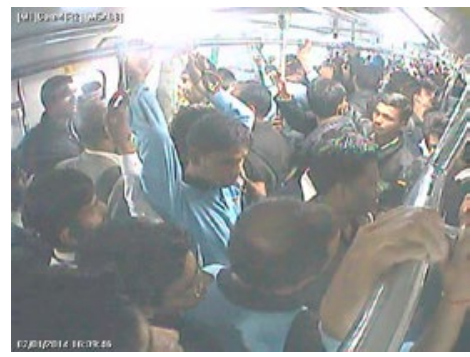

LOS D

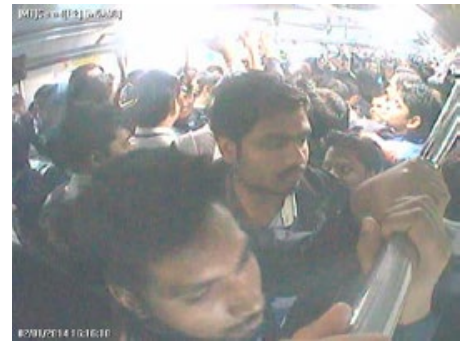

LOS E

\section{Fig. 5.}

LOS Inside Metro Train

\subsection{Level of Service (LOS) inside trains of Delhi Metro}

The LOS inside trains has been computed on the basis of criteria explained above for different lines of DMRC as presented in Table 6. The peak hour per direction traffic (PHPDT) i.e the passenger load in peak hour of the day has been considered to compute the pax/sqm inside the trains. The details of estimation of LOS are available at Annex C.

Evidently, the LOS is lowest in case of Line 2 (Jahangir puri to Huda City Center) which is considered to be the busiest line of Delhi Metro. 


\section{Table 6}

Level of Service (LOS) Inside DMRC Trains for Demand in July 2016

\begin{tabular}{|c|c|c|c|c|c|c|c|}
\hline Line & $\begin{array}{c}\text { PHPDT } \\
\text { (July16) }\end{array}$ & $\begin{array}{c}\text { Peak } \\
\text { Headway } \\
\text { (Sec) }\end{array}$ & $\begin{array}{c}\text { Trains / } \\
\text { hour }\end{array}$ & $\begin{array}{c}\text { Average } \\
\text { number } \\
\text { of cars/ } \\
\text { train }\end{array}$ & $\begin{array}{c}\text { Number } \\
\text { of cars } \\
\text { in peak } \\
\text { hours }\end{array}$ & Pax/sqm & LOS \\
\hline Line-1 (Red) & 22528 & 195 & 18.5 & 4.7 & 87 & 5.1 & $\mathrm{D}$ \\
\hline Line-2 (yellow) & 55500 & 133 & 27.1 & 7.1 & 183 & 6.1 & $\mathrm{E}$ \\
\hline $\begin{array}{c}\text { Line-3 \&4 } \\
\text { (Blue) }\end{array}$ & 45935 & 150 & 24.0 & 6.7 & 161 & 5.7 & $\mathrm{D}$ \\
\hline Line-5(Green) & 10839 & 228 & 15.8 & 4.1 & 65 & 3.4 & $\mathrm{C}$ \\
\hline Line-6(Violet) & 20229 & 200 & 18.0 & 6.0 & 108 & 3.9 & $\mathrm{C}$ \\
\hline
\end{tabular}

\section{Analysis of Results}

The Level of service has been assessed at three critical locations at Rajiv Chowk Metro station of Delhi Metro, India during peak hours using the criteria discussed above. The results are presented in Table 7 as under:

Table 7

LOS at Different Locations at Rajiv Chowk Metro Station, DMRC, India

\begin{tabular}{|c|c|c|c|c|}
\hline Location & Criteria & Time/Day & LOS & Remarks \\
\hline Walkway - F Block & Fruin's Principle (Table 1) & $\begin{array}{c}8 \mathrm{AM} \text { to } 10 \mathrm{AM} \text { on } \\
\text { Feb 24, 2014 }\end{array}$ & C & $\begin{array}{c}\text { Worst LOS observed at 9:55 } \\
\mathrm{AM}\end{array}$ \\
\hline Platform & Fruin's Principle (Table 2) & $6 \mathrm{PM}$ to 8 PM & D & $\begin{array}{c}\text { Worst LOS observed at 7 PM } \\
\text { when train is at PF }\end{array}$ \\
\hline Inside Train & Proposed Criteria (Table 3) & $8 \mathrm{AM}$ to 10 AM & E & $\begin{array}{c}\text { Worst LOS observed during } \\
\text { morning peak }\end{array}$ \\
\hline
\end{tabular}

The LOS at different locations has been presented graphically in Fig. 6 as under:

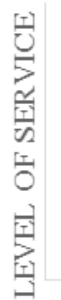

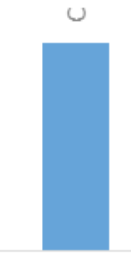

W A L K W A Y

\section{PLATFORM}

LOCATION

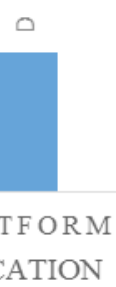

Fig. 6.

LOS at Different Locations, Rajiv Chowk Metro Station, DMRC, India

The following observations can be made from the above analysis:
- The LOS is progressively decreasing from walkway to Platform. There are 4 
walkways at Rajiv Chowk Metro station and passengers from all walkways converge at Platforms causing more congestion at platform in comparison with walkways.

- At platform, the LOS is worst when the train is at platform and arriving \& departing passengers jostle for the space.

- The Level of service is worst (E) inside the train due to heavy crowding and enclosed space.

- The objective of the any attempt to ease peak hour congestion should be to improve LOS inside the trains. Any intervention to reduce congestion inside trains would eventually help in easing congestion at platform as well as walkway. For example, if number of trains per hour (frequency) is enhanced, the clearance of passengers from platform and walkway would be better and congestion will be reduced at platform as well as walkway.

\section{Strategies to Ease Congestion Inside Metro Trains}

Having assessed the congestion inside metro trains using LOS concept, the next step is to ease congestion by deploying suitable measures. The congestion can be eased broadly by two ways- increasing supply called supply side measures, controlling demand called demand side measures. The following supply and demand side measures can be adopted to ease congestion inside metro trains during peak hours:

a) Supply side measures:

a. Increase Trains per hour (Frequency);

b. Increase length of the train (Cars per train); c. Increase average speed of the train and thus frequency of trains with same number of train sets;

d. Improve Train control system to allow trains to run at closer headway;

b) Demand side measures:

a. Differential Fares-higher fares during peak hours;

b. Integration with other modes of transport;

c. Network Design-Multiple interchange points;

d. Time Tabling - Supply more than demand in off peak hours to attract leisure travellers/SrCitizens etc in off peak hours.

The above list of supply and demand side measures is not exhaustive but is illustrative in nature. The operational capacity of Delhi Metro trains has been defined as 6 pax/sqm. Keeping this as benchmark, the LOS of D shall be the target to be achieved by deploying an optimum combination of supply and demand management (Button, 1983; TRL, 2004) measures.

\section{Conclusion}

The congestion in the metro rail system especially during peak hours is being faced by most of the metro systems in the major cities of the world. The strategy to ease peak hour congestion shall focus on some objective method of assessing the congestion in metro rail area and adopting effective measures to ease congestion. The Level of Service (LOS) is a measurable parameter which may be used to assess the congestion in metro environment. The most vulnerable areas of congestion in a metro rail system are walkways, platform and the trains. An 
observation of LOS at walkway, platform and inside the train at the busiest station (Rajiv Chowk) of Delhi Metro, India reveals that the congestion inside trains is the worst. Any measure to ease congestion in metro trains is also likely to ameliorate congestion at other critical locations of the station. A metro operator can deploy a combination of supply and demand management measures to ease congestion inside metro trains with an objective to achieve an acceptable LOS. The acceptable LOS inside metro trains may be fixed the management of the metro train operator or the government. An LOS less than the acceptable LOS shall call for positive intervention by the metro train operator. The LOS may also be used as an efficiency parameter for defining Key performance Indicators (KPI) for a metro train operator.

\section{References}

Aftabuzzaman, M. 2007. Measuring Traffic Congestion-A Critical Review. In Proceedings of the $30^{\text {nd }}$ Australasian Transport Research Forum, $16 \mathrm{p}$.

Broaddus, A.; Litman, T.; Menon, G. 2009. Transport Demand Management-Training Document. Available from internet: <http://transport-indonesia.org/>.

Button. J.K. 1983. Transport Economics, $2^{\text {nd }}$ Edition. Edward Elgar, Cheltenham. GB. 265 p.
Fruin, J.J. 1987. Pedestrian Planning and Design. Revised Edition, Elevator World, Inc., Mobile. AL. 206 p.

Hale, C.; Charles, P. 2009. Managing Peak Hour Demand for Passenger Rail: A Literature Review, In Proceedings of the $32^{\text {nd }}$ Australasian Transport Research Forum, $15 \mathrm{p}$.

Henn, L.; Karpouzis, G.; Sloan, K. 2010. A review of policy and economic instruments for peak demand management in commuter rail. In Proceedings of the $33^{\text {nd }}$ Australasian Transport Research Forum, 13 p.

Roess, R.P.; Messer, C.J.; Mcshane, W.R.; Fruin, J.J.; Levinson, H.S.; May, A.D.; Dudek, C.L. 1985a. Chapter 3 of Transit Service and Quality of Service Manual- $2^{\text {nd }}$ Edition on Passenger Circulation and Level of service. Available from internet: <http://www.trb.org >.

Roess, R.P.; Messer, C.J.; Mcshane, W.R.; Fruin, J.J.; Levinson, H.S.; May, A.D.; Dudek, C.L. 1985b. Chapter 4 of Transit Service and Quality of Service Manual - $2^{\text {nd }}$ Edition on Passenger Circulation and Level of service. Available from internet: <http:// www.trb.org>.

TRL. 2004. The Demand for Public Transport: a practical guide - TRL Report 593. Available from internet: <https://trl.co.uk>. 


\section{Exhibit 1}

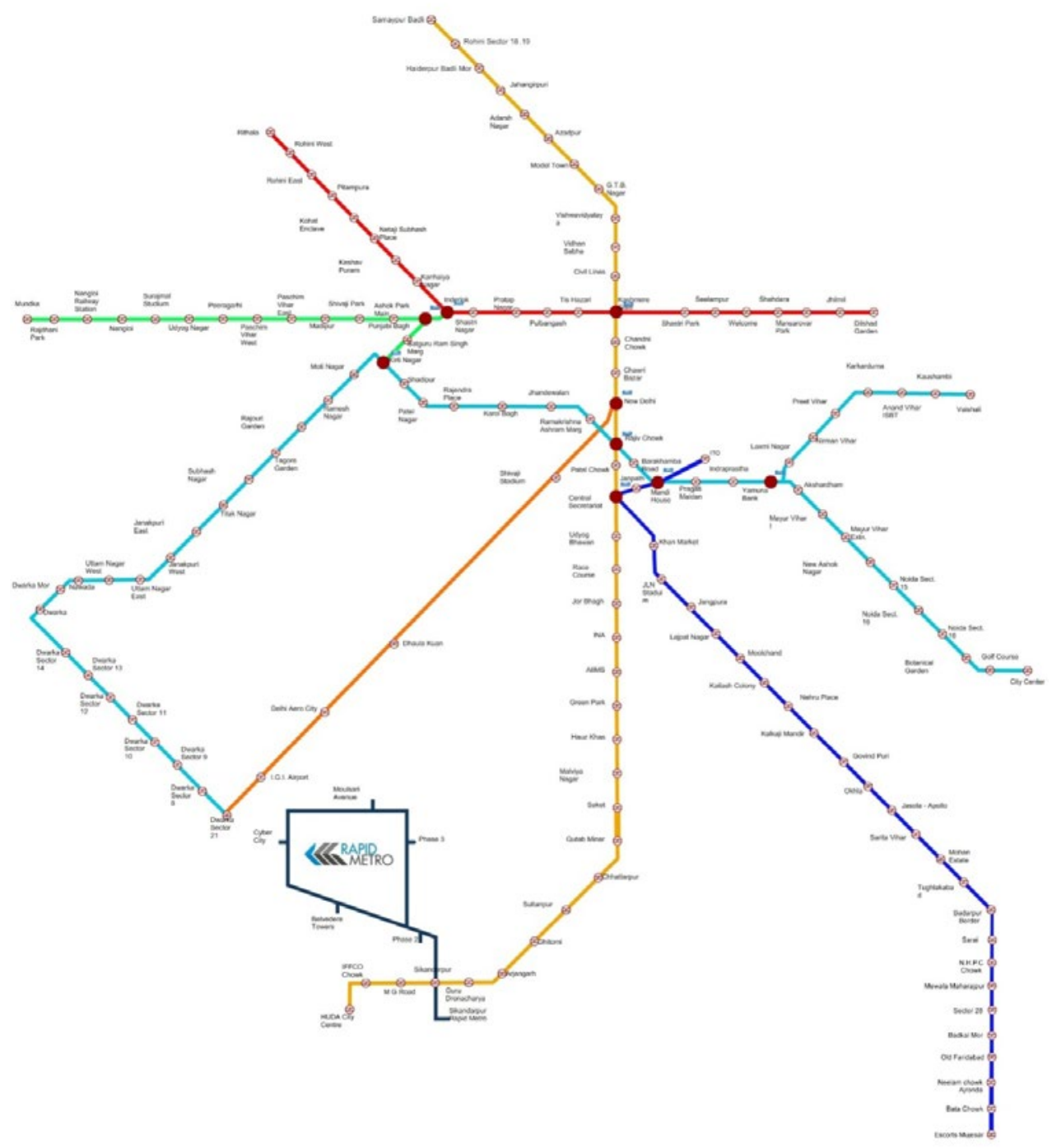

Fig. E1.

Present Network of Delhi Metro (March 2016)

(Source: DMRC website, http://www.delhimetrorail.com/Zoom_Map.aspx) 


\section{Annex A}

Table A1

Assessment of Level of Service in F Block of Rajiv Chowk Metro Station

\begin{tabular}{|c|c|c|c|c|c|c|}
\hline & $\begin{array}{c}\text { Number of pax in } \\
\text { observed area }\end{array}$ & Time & P/Sqm & $\begin{array}{c}\text { Avg Speed } \\
(\mathbf{m} / \mathbf{m i n})\end{array}$ & $\begin{array}{c}\text { Avg Flow/Unit } \\
\text { Width (p/m/min) }\end{array}$ & LOS \\
\hline 1 & 14 & $08: 02: 53$ & 0.14 & 90.43 & 3 & $\mathrm{~A}$ \\
\hline 2 & 8 & $08: 34: 52$ & 0.08 & 84.40 & 4 & $\mathrm{~A}$ \\
\hline 3 & 20 & $09: 04: 57$ & 0.19 & 84.40 & 10 & $\mathrm{~A}$ \\
\hline 4 & 25 & $09: 33: 15$ & 0.24 & 79.13 & 14 & $\mathrm{~A}$ \\
\hline 5 & 34 & $09: 51: 42$ & 0.33 & 79.13 & 23 & $\mathrm{~B}$ \\
\hline 6 & 55 & $09: 54: 46$ & 0.53 & 74.47 & 23 & $\mathrm{C}$ \\
\hline
\end{tabular}

Date: Feb 24, 2014, Time 8 AM to 10 AM (Morning Peak)

\section{Annex B}

\section{Assessment of Level of Service at Platform of Rajiv Chowk Metro Station}

Table B1

Congestion at Platform

\begin{tabular}{|c|c|}
\hline \multicolumn{2}{|c|}{ Rajiv Chowk, Down Platform (Yellow Line) } \\
Date: April 21, 2014 \\
\hline Time & $18: 00-20: 00$ \\
\hline Length & $9.6 \mathrm{~m}$ \\
\hline Width & $3.6 \mathrm{~m}$ \\
\hline Area & $34.56 \mathrm{~m}^{2}$ \\
\hline
\end{tabular}

Table B2

Platform: Before Arrival of Train

\begin{tabular}{|c|c|c|c|c|c|}
\hline S1 No & Passengers & Time & P/Sqm & Avg Inter personal Spacing (m) & Level \\
\hline 1 & 60 & $18: 00: 17$ & 1.74 & 0.86 & D \\
\hline 2 & 75 & $18: 31: 41$ & 2.17 & 0.77 & D \\
\hline 3 & 50 & $19: 00: 39$ & 1.45 & 0.94 & C \\
\hline 4 & 70 & $19: 31: 03$ & 2.03 & 0.79 & D \\
\hline 5 & 65 & $19: 46: 51$ & 1.88 & 0.82 & D \\
\hline
\end{tabular}

Table B3

Platform: With Train

\begin{tabular}{|c|c|c|c|c|c|}
\hline S1 No & Passengers & Time & P/Sqm & $\begin{array}{c}\text { Avg Inter personal Spacing } \\
(\mathbf{m})\end{array}$ & Level \\
\hline 1 & 90 & $18: 00: 56$ & 1.80 & 0.70 & D \\
\hline 2 & 120 & $18: 32: 14$ & 2.40 & 0.61 & D \\
\hline 3 & 75 & $19: 01: 13$ & 1.50 & 0.77 & C \\
\hline 4 & 85 & $19: 31: 35$ & 1.70 & 0.72 & D \\
\hline 5 & 95 & $19: 47: 30$ & 1.90 & 0.68 & D \\
\hline
\end{tabular}




\section{Table B4}

Platform: After Departure of Train

\begin{tabular}{|c|c|c|c|c|c|}
\hline SI No & Passengers & Time & P/Sqm & $\begin{array}{c}\text { Avg Inter personal Spacing } \\
(\mathbf{m})\end{array}$ & Level \\
\hline 1 & 40 & $18: 01: 48$ & 0.53 & 1.05 & $\mathrm{~A}$ \\
\hline 2 & 43 & $18: 34: 00$ & 0.57 & 1.01 & $\mathrm{~A}$ \\
\hline 3 & 55 & $19: 02: 27$ & 0.73 & 0.89 & $\mathrm{~A}$ \\
\hline 4 & 29 & $19: 32: 38$ & 0.39 & 1.23 & $\mathrm{~A}$ \\
\hline 5 & 16 & $19: 48: 36$ & 0.21 & 1.66 & $\mathrm{~A}$ \\
\hline
\end{tabular}

\section{Annex C}

On 02.01.2014 an experiment was conducted to measure level of service inside metro trains for different number of the passengers. The experiment was conducted in one of the train parking depot of Delhi Metro Rail Corporation (DMRC), India using 300 trainees of DMRC training institute.

\section{C. Measurement of Level of Service Inside Metro Train}

There are three types of cars in a train:

- DT- Driving Car having driver's cab;

- M- Motor car having traction motor;

- T- Trailing car having other equipment.

The standing and sitting capacity of RS1 type rolling stock of Delhi Metro is as under Table C1:

\section{Table C1}

Standing Area and Seating Capacity of Different Trains, Delhi Metro, India

\begin{tabular}{|c|c|c|c|c|c|}
\hline $\begin{array}{l}\text { Type of } \\
\text { train }\end{array}$ & Type of car & Area (Sqm) & $\begin{array}{c}\text { Average } \\
\text { area }(\mathbf{S q m})\end{array}$ & $\begin{array}{l}\text { Seating } \\
\text { capacity }\end{array}$ & $\begin{array}{c}\text { Average } \\
\text { seating } \\
\text { capacity }\end{array}$ \\
\hline \multirow{3}{*}{ RS1 } & DT & 39.77 & \multirow{3}{*}{41.80} & 43 & \multirow{3}{*}{47.67} \\
\hline & $\mathrm{M}$ & 42.82 & & 50 & \\
\hline & $\mathrm{T}$ & 42.82 & & 50 & \\
\hline \multirow{3}{*}{ RS2 } & DT & 39.75 & \multirow{3}{*}{40.75} & 42 & \multirow{3}{*}{47.33} \\
\hline & $\mathrm{M}$ & 41.25 & & 50 & \\
\hline & $\mathrm{T}$ & 41.25 & & 50 & \\
\hline \multirow{3}{*}{ RS3 } & DT & 34 & \multirow{3}{*}{35.47} & 43 & \multirow{3}{*}{47.67} \\
\hline & $M$ & 36.2 & & 50 & \\
\hline & $\mathrm{T}$ & 36.2 & & 50 & \\
\hline
\end{tabular}

The experiment has been done on DT car of RS1 train. The users were allowed to enter into the car as per following Table C2 


\section{Table C2}

Stepwise User Entry criteria during experiment

\begin{tabular}{|c|c|c|}
\hline Step & Criteria & Number \\
\hline 1 & Only sitting & 43 \\
\hline 2 & Sitting $+2 \mathrm{pax} / \mathrm{sqm}(43+2 \times 39.77)$ & 123 \\
\hline 3 & Sitting $+3 \mathrm{pax} / \mathrm{sqm}(43+3 \times 39.77)$ & 163 \\
\hline 4 & Sitting $+4 \mathrm{pax} / \mathrm{sqm}(43+3 \times 39.77)$ & 202 \\
\hline 5 & Sitting $+5 \mathrm{pax} / \mathrm{sqm}(43+3 \times 39.77)$ & 242 \\
\hline 6 & Sitting $+6 \mathrm{pax} / \mathrm{sqm}(43+3 \times 39.77)$ & 282 \\
\hline
\end{tabular}

\section{C. Assessment of Level of Service Inside Trains for Different Lines of DMRC}

On the basis of proposed criteria of assessment of LOS in Table 4, the LOS has been assessed across different lines of Delhi Metro, India as presented in Table C3.

Table C3

Level of Service (LOS) Inside DMRC Trains, India

\begin{tabular}{|c|c|c|c|c|c|c|c|c|c|c|c|c|c|}
\hline \multirow[b]{2}{*}{$\stackrel{\Xi}{\Xi}$} & \multirow[b]{2}{*}{ 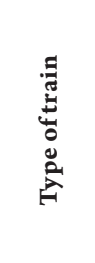 } & \multirow[b]{2}{*}{ 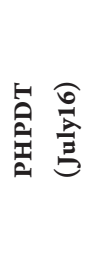 } & \multirow{2}{*}{ 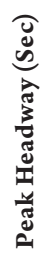 } & \multirow[b]{2}{*}{ 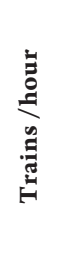 } & \multicolumn{4}{|c|}{ Number of trains } & \multirow[b]{2}{*}{ 劳 } & \multirow[b]{2}{*}{ 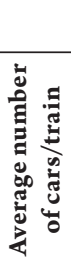 } & \multirow[b]{2}{*}{ 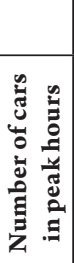 } & \multirow[b]{2}{*}{ 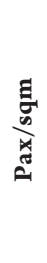 } & \multirow[b]{2}{*}{$\stackrel{\infty}{0}$} \\
\hline & & & & & $\underset{t}{U}$ & ט & $\cup$ & 륨 & & & & & \\
\hline Line-1 & RS1 & 22528 & 195 & 18.5 & 19 & 10 & 0 & 29 & 136 & 4.7 & 87 & 5.1 & $\mathrm{D}$ \\
\hline Line-2 & RS1\&2 & 55500 & 133 & 27.1 & 0 & 27 & 33 & 60 & 426 & 7.1 & 183 & 6.1 & $\mathrm{E}$ \\
\hline $\begin{array}{c}\text { Line-3 } \\
844\end{array}$ & RS1\&2 & 45935 & 150 & 24.0 & 0 & 46 & 25 & 71 & 476 & 6.7 & 161 & 5.7 & $\mathrm{D}$ \\
\hline Line-5 & RS3 & 10839 & 228 & 15.8 & 22 & 1 & 0 & 23 & 94 & 4.1 & 65 & 3.4 & $\mathrm{C}$ \\
\hline Line- 6 & RS3 & 20229 & 200 & 18.0 & 0 & 44 & 0 & 44 & 264 & 6.0 & 108 & 3.9 & $\mathrm{C}$ \\
\hline
\end{tabular}

